\title{
Digitally Reinforced Polarization of Hematoxylin-Eosin in the Diagnosis of Renal Amyloidosis
}

\section{Renal Amiloidoz Tanısında Dijital Güçlendirilmiş Hematoksilen Eozin Polarizasyonu}

\author{
Sait ŞEN, Banu SARSIK KUMBARACI \\ Department of Medical Pathology, Ege University, Faculty of Medicine, IZMIR, TURKEY
}

The summary of this study was presented at 24th Congress of Pathology held in Prague on 8-12 September 2012

\begin{abstract}
Objective: Systemic amyloidosis is a rare disorder, characterized by extracellular accumulation of Congo red positive fibrillar amyloid protein deposits that have an amorphous, eosinophilic appearance on hematoxylin-eosin stained preparations. The kidney is the most commonly affected organ by systemic amyloidosis. Congo red staining increases the positive birefringence of the weakly birefringent unstained amyloid. In this study, we investigated the potential diagnostic power of digitally reinforced birefringence of routine hematoxylin-eosin stained slides from renal biopsies.
\end{abstract}

Material and Method: We reviewed 130 hematoxylin-eosin stained slides for polarization. Sixty-five new amyloidosis cases were diagnosed by renal biopsy. All renal biopsies were evaluated by light microscopy and immunofluorescence. Slides were reevaluated blindly using a microscope (Olympus BX51) that was attached polarization filters and connected to a digital camera (Olympus DP21, SAL). Deposits that showed green birefringence on hematoxylin-eosin preparations with digitalized microscopy were considered positive and the results were confirmed using Congo red.

Results: Of the 65 Congo red confirmed amyloid positive biopsies, 61 showed green birefringence with hematoxylin-eosin. Of the 65 Congo-red confirmed amyloid negative biopsies, two were considered to be false positive. The sensitivity, specificity, and positive and negative predictive values were estimated as $94 \%, 97 \%, 97 \%$ and $94 \%$ respectively.

Conclusion: We concluded that polarized hematoxylin-eosin sections can be used digitally as a fast and first step diagnostic method for renal amyloidosis

Key Words: Amyloid, Amyloidosis, Congo Red, Hematoxylin

\section{ÖZ}

Amaç: Sistemik amiloidozlar, hematoksilen-eozin boyamada amorf eozinofilik görülen, Kongo kırmızısı ile boyanan fibriller amiloid proteinlerin ekstrasellüler birikimiyle karakterize nadir hastalıklardır. Böbrekler sistemik amiloidozlardan en sık etkilenen organdır. Kongo kırmızısı, zayıf birefrenjant boyanmamış amiloidin birefranjansını artırır. Bu çalışmada, böbrek biopsilerinin rutin hematoksilen eozin kesitlerinde dijital güçlendirilmiş birefrenjansın potansiyel tanısal gücünü araştırdık.

Gereç ve Yöntem: Hematoksilen-eozin boyalı 130 preparat polarizasyon için değerlendirildi. Altmış beş yeni amiloidoz olgusuna böbrek biyopsisi ile tanı konuldu. Tüm böbrek biopsileri 1şık ve immünflöresan mikroskop ile değerlendirildi. Preparatlar kör olarak, polarizasyon filtreleri eklenmiş ve digital kamera (Olympus DP21, SAL) bağlanmış mikroskopla (Olympus BX51) değerlendirildi. Dijitalize mikroskopi ile yeşil birefrenjans gösteren birikimler pozitif olarak değerlendirildi ve Kongo kırmızısı ile birikimler doğrulandı.

Bulgular: Kongo kırmızısı ile doğrulanmış 65 amiloid pozitif biopsinin 61'i hematoksilen-eozin ile yeşil birefrenjans gösterdi. Kongo kırmızısı ile doğrulanmış, 65 amiloid birikimi olmayan olgunun 2'si yalancı pozitif olarak değerlendirildi. Duyarlılık, özgüllük, pozitif ve negatif prediktif değerler sırasıyla \%94, \%97, \%97 ve $\% 94$ olarak hesapland.

Sonuç: Renal amiloidoz için polarize edilmiş hematoksilen eozin kesitler dijital olarak hızlı ve ilk basamak tanı metodu olarak kullanılabilir.

Anahtar Sözcükler: Amiloid, Amiloidozis, Kongo kırmızısı, Hematoksilen
(Turk Patoloji Derg 2012, 28:204-212)

Received : 27.04.2012 Accepted : 14.06.2012
Correspondence: Sait ŞEN

Department of Medical Pathology, Ege University, Faculty of Medicine,

IZMIR, TURKEY

E-mail: sait.sen@ege.edu.tr Phone: +905334241669 


\section{INTRODUCTION}

Amyloidosis is caused by the systemic or localized accumulation of at least 27 different proteins (1). Systemic forms involve the internal organs at different rates, and the kidneys are important within these affected organs in terms of morbidity and mortality. Incidence in kidney biopsies in the adult population is under 2\% in American and European publications, but reaches $10 \%$ in our country (2-7).

Amyloid deposits appear pink under light microscopic investigation of routine hematoxylin-eosin (H\&E) sections in kidney biopsies and can be confused with findings such as hyalinosis and sclerosis that can cause a similar appearance (8). Staining of the eosinophilic deposits with Congo red (CR) and making the diagnosis with apple green polarization is accepted as the gold standard for amyloidosis diagnosis (1, 8-11). Unstained amyloid deposits show weak birefringence and the CR staining increases this birefringence (9). Histochemical staining methods such as Schiff's periodic acid (PAS), Masson's trichrome (MT) and Jones's methenamine silver (JMS) used during routine evaluation of kidney biopsies are helpful in the differential diagnosis (8). However, amorphous eosinophilic deposits in biopsies of cases where CR is not used routinely and do not have a clinical suspicion of amyloidosis may not receive an amyloidosis diagnosis.

Kidney needle biopsies and needle or endoscopic biopsies of other organs are small in size, and the optimal evaluation and preservation of tissue are therefore important. Preparing new sections for methods requiring a thick section such as CR staining can also deplete the tissue in paraffin blocks in small biopsies and there may not be enough tissue for further investigations. Therefore, the optimum evaluation of small biopsies that create differential diagnosis difficulties and require advanced investigation is extremely important. During the evaluation of cases with amyloidosis, we observed that the amyloid deposits show very weak polarization under strong light in routine $\mathrm{H} \& \mathrm{E}$ stained preparations. We therefore planned this study to determine whether $\mathrm{H} \& \mathrm{E}$ polarization can be used as an additional method in kidney needle biopsies for amyloidosis diagnosis and whether its enhancement by digitalization will contribute to the diagnosis of amyloidosis.

\section{MATERIAL and METHODS}

We included 65 cases diagnosed with amyloidosis at Ege University Medical Faculty Pathology Department between 2008 and 2012 and a total of 65 cases with amorphous eosinophilic deposits suspicious in terms of amyloid in the differential diagnosis following renal needle biopsy, including diabetic glomerulosclerosis (25 cases), segmental sclerosis and/or glomerulonephritis associated with fibrinoid necrosis and ANCA (20 cases), and myeloma cast nephropathy (15 cases) in the study. In addition, 15 cases, including previously published ones, diagnosed with amyloidosis localized to the seminal vesicle determined in cases evaluated for prostate adenocarcinoma were included as non-renal positive control cases (12).

The clinical and laboratory data of the cases with a diagnosis of amyloidosis that were included in the study were investigated from the hospital archive records.

Light microscopic examination: Renal needle biopsies were evaluated with three 3-4 micron thick H\&E stained slides of different levels as well as JMS, MT, PAS, and Putchtler's modified CR method during the histochemical examination (11). Antibodies marked with fluorescent isothiocyanate were used for IgG, IgM, IgA, kappa, lambda, $\mathrm{Clq}, \mathrm{C} 3 \mathrm{c}$, and fibrinogen for the immunofluorescence microscopic investigation. Amyloidosis was diagnosed by the deposits staining CR positive with the Putchler staining method showing apple-green polarization on the polarizing microscope and these cases were evaluated as systemic amyloidosis. In cases with amyloidosis, scoring and staging were performed according to the renal amyloidosis histological classification (6).

Typing of amyloid deposits: Immunohistochemical (IHC) investigation with antibodies against kappa, lambda, prealbumin (TTR), fibrinogen, lysozyme and AA was used to type the amyloid preliminary proteins of the cases with amyloidosis. IHC staining was performed with a fully automated device (Benchmark XT, Ventana Medical Systems, Tucson, USA) (Table I). IHC staining in amyloid deposit areas was scored as negative (0) or positive (in 4 values as,,,++++++++++ according to the severity of staining). In non-AA amyloidosis cases, concurrent minimal positivity with anti-AA antibody was not taken into account for typing. Typing was performed together with clinical and laboratory findings in cases where we were not able to perform reliable typing with multiple positive IHC results.

Digital imaging method: The main feature of this study is digital imaging and photography of $\mathrm{H} \& \mathrm{E}$ polarization. The light intensity of the microscope and the setting of the camera were optimized as they are important for the imaging method. The polarization of the amyloid deposits is difficult to recognize under microscope ocular in $\mathrm{H} \& \mathrm{E}$ stained sections during normal light microscopic examination. The amyloid deposit polarization is best 
Table I: Antibodies and dilutions used for the immunohistochemical typing of amyloid proteins

\begin{tabular}{|l|l|l|l|l|}
\hline Antibody & Antigen & Clonality & Company & Dilution \\
\hline AA Amyloid & clone mc1 & Monoclonal & M0759 Dako & $1 / 100$ \\
\hline lambda light chain & HP6054 & Polyclonal & Neomarker & $1 / 400$ \\
\hline Kappa light chain & Kap03 & Polyclonal & Neomarker & $1 / 1000$ \\
\hline Fibrinogen & & Polyclonal & A0080 Dako & $1 / 5000$ \\
\hline Lysozyme & & Polyclonal & A0099 Dako & $1 / 400$ \\
\hline Prealbumin (TTR) & transthyretin & Polyclonal & A0002 Dako & $1 / 1000$ \\
\hline
\end{tabular}

recognized and photographed on the screen on a dark background, with 2 seconds of exposure time during polarization and the automatic exposure setting of the DP21 camera system attached to the microscope. CR also shows the best birefringence under these settings.

H\&E and CR stained sections of all biopsies were investigated in 10 times enlarged (Plan apochromat) format, with the light source completely open, and the polarization images of amorphous eosinophilic deposits were digitally transferred to the monitor (AOC, TFT19W80PSA+, China) to be simultaneously evaluated and photographed. A microscope (Olympus BX51TF ve U-LH100) with a DP21 Olympus camera (DP21 SAL, U-TV0.5XC-3), polarization (U-POT, U-ANT) and a multi-observer attachment (U-MDOB3) was used for the digital imaging process.

The images of amyloid and suspicious deposits regarding the differential diagnosis were evaluated and photographed on the DP21 monitor using the automatic exposure setting, normal light and polarization. Before starting the study, 100, 200 , and 400 ASA settings were compared to the automatic and manual exposure of the camera for optimization (Figure 1A-D). After the optimization and standardization of the photography, all images were investigated on the monitor and were simultaneously photographed using $1600 \times 1200$ pixel and 100 ASA values. During polarization, we made sure the camera exposure duration was $2 \mathrm{sec}$. (the highest level) and the background was at its darkest.

During the study, it was possible to evaluate some cases as suspicious or negative as amyloid deposits were few in number and it was not possible to fully evaluate an applegreen appearance on the monitor. In such cases, a second evaluation was performed using photographs taken during the assessment. The digital photos were re-evaluated on a laptop (MacBook Pro, 13 inch, 2,3 GHz, Core i5 processor) using Picasa 3 (Picasa 3.9.7.585, Google Inc.) photography software. In this evaluation, we focused on the areas we wanted to analyze in detail with different digital magnifications and investigated the polarization color.
The sensitivity, specificity, accuracy, and positive and negative predictive values of $\mathrm{H} \& \mathrm{E}$ polarization were statistically calculated.

\section{RESULTS}

A total of 65 cases were diagnosed with amyloidosis during the study period. The clinical and histopathological typing features of the cases are presented in Table II.

Amyloid deposits showed typical apple-green birefringence under polarized light using digital imaging methods after both $\mathrm{H} \& \mathrm{E}$ and CR staining in all cases with prostate carcinoma and seminal vesicle amyloidosis that were used as a positive control for non-renal amyloid deposits (Figure 2A-C).

$H \& E$ polarization could not be seen in only 4 of 65 patients diagnosed with amyloidosis and these were evaluated as false negative. In two of these cases the deposits were minimal and reflected early period deposits. The remaining two had deposits that were prominent in glomerular capillaries with obliteration, reflecting the later period.

$\mathrm{H} \& \mathrm{E}$ polarization images were lighter than $\mathrm{CR}$ polarization in cases with renal amyloidosis (Figure 3A-D). We were not able to evaluate the relationship between the deposited amyloid protein type and $\mathrm{H} \& \mathrm{E}$ polarization negativity as the cases without $\mathrm{H} \& \mathrm{E}$ polarization were few and the amyloid subtypes deposited in these cases were heterogeneous (Table II).

Of the 65 cases used as negative control that had glomerular and tubular pathologies that could be confused with amyloidosis, deposits in the perivascular interstitial area were evaluated as positive although they were not typical only in two cases (Figure 4A-H). The images of these positive cases that were evaluated as false positive do not give rise to any suspicion on $\mathrm{H} \& \mathrm{E}$ investigation in terms of amyloidosis and are not typical for amyloid deposits but show yellow-green polarization. 

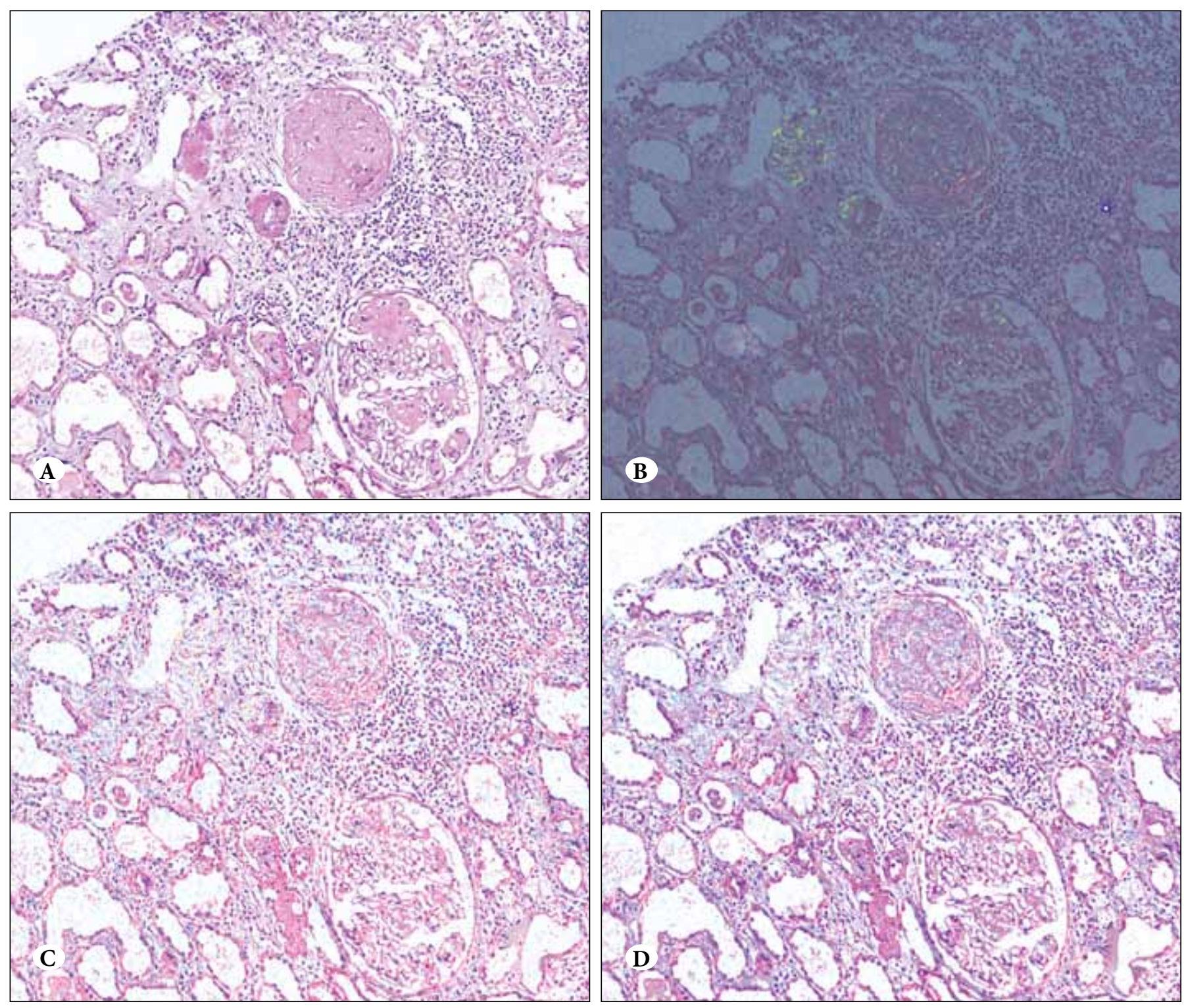

Figure 1: Hematoxylin-eosin section polarization appearance on 100, 200, 300 and 400 ASA in the DP-21 SAL system with automatic settings: (A) (B) 100, (C) 200, and (D) 400 ASA appearance (x100) with hematoxylin-eosin, normal light and polarization.

Table II: Typing characteristics of the cases with renal amyloidosis in the study

\begin{tabular}{|l|c|c|}
\hline & Case $\mathbf{n}(\%)$ & False negative n (\%) \\
\hline AA amyloidosis & $40(62)$ & $2(5)$ \\
\hline Non-AA amyloidosis & $12(18)$ & $1(8)$ \\
\hline Untyped amyloidoses & $13(20)$ & $1(8)$ \\
\hline
\end{tabular}

(61 native and, 4 transplant kidneys. All false negatives were in native kidneys).

Table III: The distribution of true and false positivity and negativity in 130 cases in the study

\begin{tabular}{|l|c|c|}
\hline & True (Correct diagnosis) & False (Wrong diagnosis) \\
\hline Positive (cases with amyloidosis diagnosis) & 61 & 4 \\
\hline Negative (cases without amyloid deposits) & 63 & 2 \\
\hline
\end{tabular}



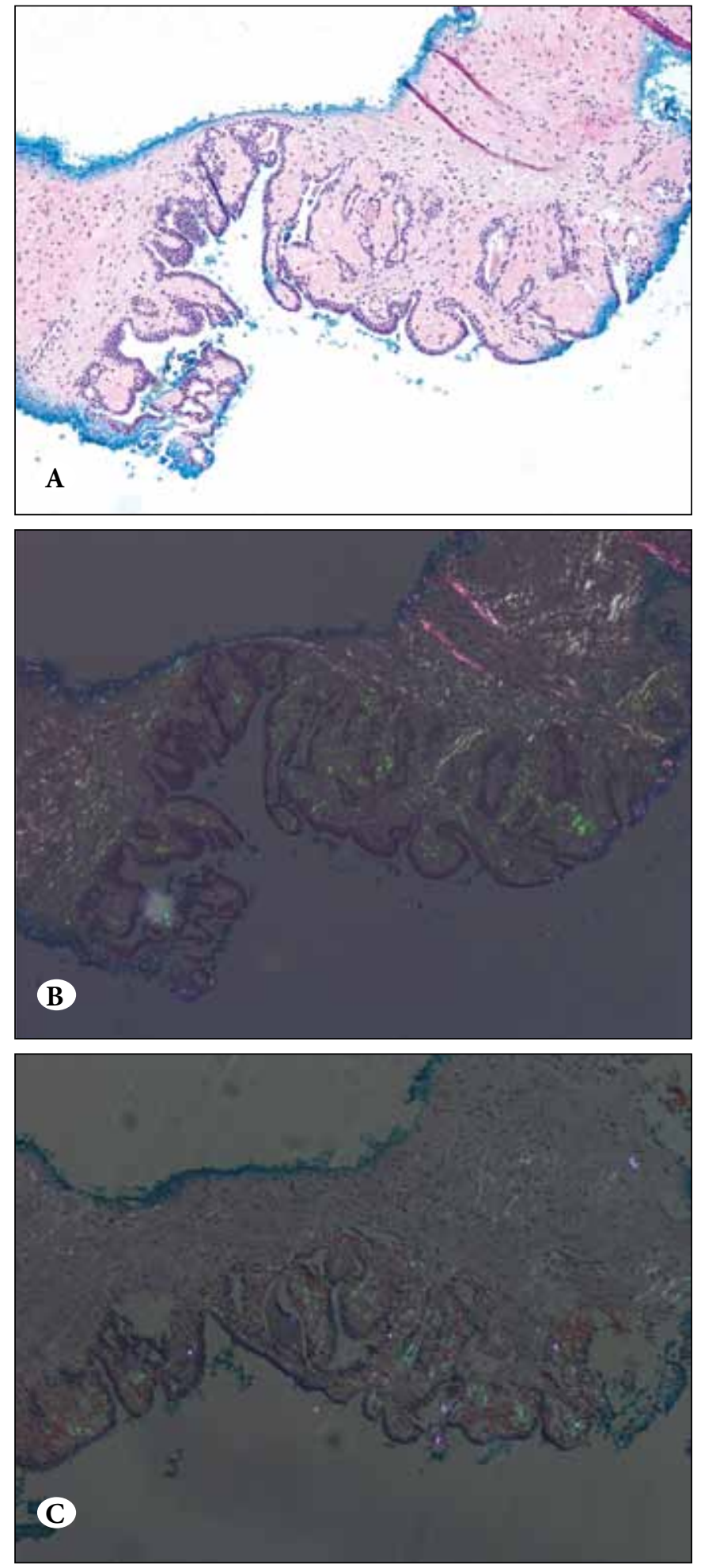

Figure 2: Amyloidosis of the seminal vesicle in prostate needle biopsy: (A) Hematoxylin-eosin, (B) Hematoxylin-eosin polarization is associated with birefringence of white collagen other than the green color, $(\mathbf{C})$ Congo red polarization: green birefringence and the original red color of Congo red on the background are seen with Congo red polarization.
Four of the 130 cases in total in the renal series in this study were evaluated as negative and two as false positive (Table III). The sensitivity, specificity, accuracy, and positive and negative predictive values of $\mathrm{H} \& \mathrm{E}$ polarization of amyloid accumulations being displayed with digital imaging were statistically calculated as $94 \%, 97 \%, 95 \%, 97 \%$ and $94 \%$ respectively.

\section{DISCUSSION}

Amorphous eosinophilic deposits can be suspicious in terms of amyloidosis during the evaluation of H\&E stained sections of biopsies. Areas such as sclerosis and hyalinization that have a similar morphological appearance create difficulties in the differential diagnosis. The polarization of foreign substances in the tissue and the collagen fibers of the mature bone tissues can be observed. During the evaluation of $\mathrm{H} \& \mathrm{E}$ stained sections with routine light microscopy, amyloid fibrils not stained with any staining method are also reported to show birefringence (9). However, our observations in our few cases do not validate this. There is no information on the routine use of $\mathrm{H} \& \mathrm{E}$ polarization in detecting amyloid deposits. Typical applegreen polarization of amyloid deposits in the H\&E stained sections were shown with the help of digital imaging and its validation with $C R$ was performed in this study for the first time. This study demonstrates digitally reinforced H\&E polarization being used together with $\mathrm{CR}$ as an ancillary method and as a first step in determining amyloid deposits in renal biopsies.

Amyloid deposits are diagnosed following the deposit of at least 27 different preliminary proteins in the tissue with a typical Beta layer sequence and demonstration of typical apple green birefringence with polarization on the light microscope when stained with CR (1). CR staining and polarization are currently the golden standard for a definitive diagnosis. However, some difficulties of the CR staining method such as requiring a thick section reaching 12 micron thickness and optimization of the staining method are known $(1,10,11)$. Thioflavin $S$ and $T$, the metachromatic stains of toluidine, methyl or crystal violet as well as CR fluorescence are ancillary methods in amyloidosis diagnosis (10,11,13-15). Amyloid stains are generally used in renal biopsies in our country while they are only used if there is a clinical and pathological suspicion of amyloid deposits in other organ biopsies. This study indicates that amyloid deposits can be diagnosed with H\&E staining method without the need for an additional polarization, with a high degree of specificity and sensitivity, using archive sections during routine histological evaluation and photography. This may reduce the need for CR application or may make it 

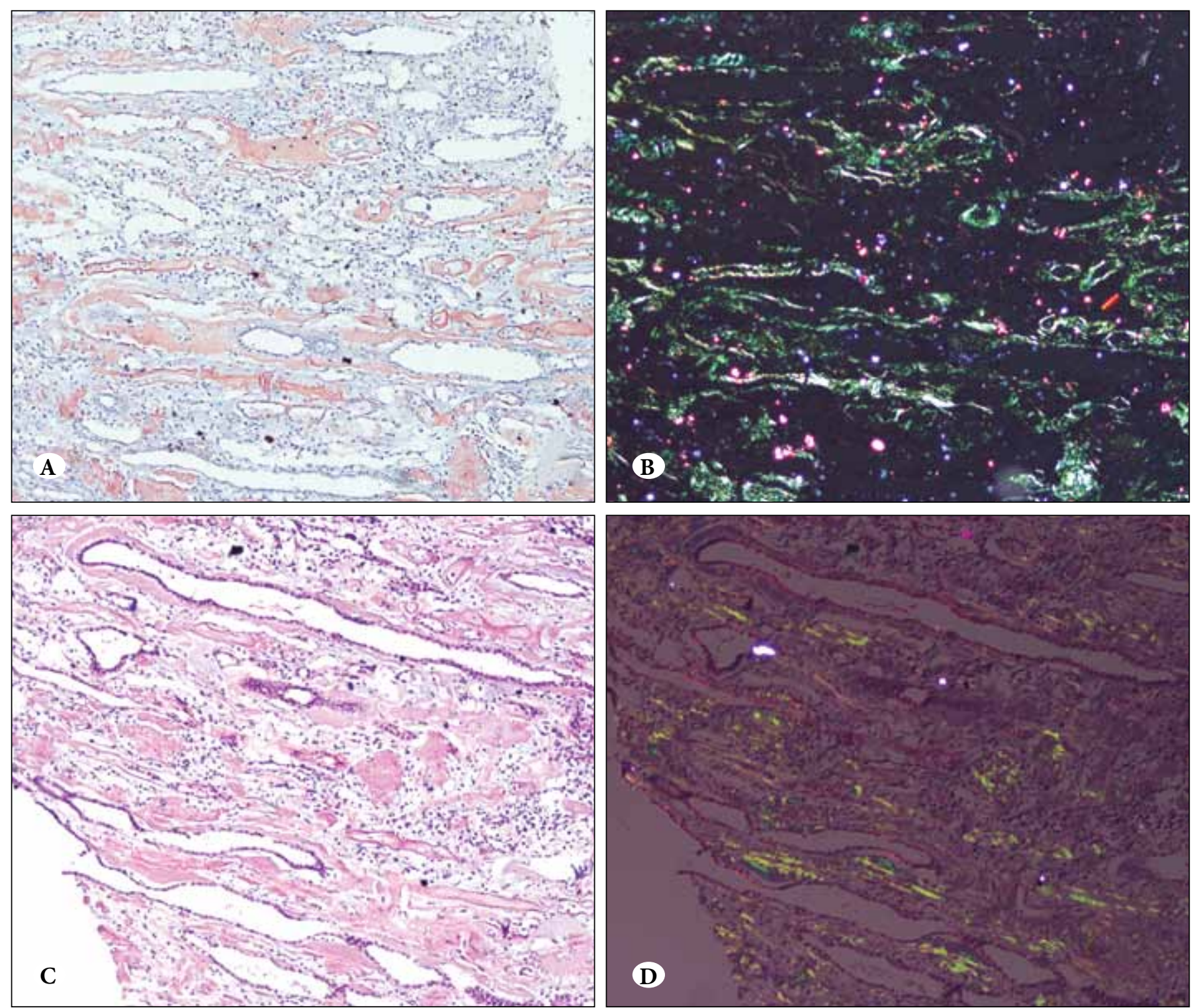

Figure 3: Comparison of the polarization with the Congo red and hematoxylin-eosin staining methods in a case with marked medullary interstitial amyloid deposits on original preparations, diagnosed without preparing new sections: (A) Congo red, (B) Congo red polarization, (C) Hematoxylin-eosin, (D) Hematoxylin-eosin polarization (x100).

possible to ask for early staining for immunohistochemical typing of amyloid proteins without waiting for CR result.

There is controversy regarding the apple green color of the amyloid deposits in polarization with CR. Besides the various shades of green and blue with polarization, all deposits not simultaneously showing polarization are defined as anomalous color change and this can be seen in pictures in the publications. Howie et al. recently emphasized this (16-18). Our findings indicate that all deposits do not simultaneously show polarization on $\mathrm{H} \& \mathrm{E}$ polarization where the polarization is in typical apple green color and is less than the polarization with CR. The eosin part of $H \& E$ seems to be responsible for the birefringence. No apple green color change was observed in a small number of sections stained with hematoxylin but polarization was observed in sections stained with eosin only.

Amyloid deposits in different areas of the kidney were seen in green in renal biopsies with $\mathrm{H} \& \mathrm{E}$ polarization while fibrosis and connective tissue areas can give yellow polarization. These two latter cases were therefore evaluated as false positive. When we reevaluated these cases, it was revealed that this image was incorrectly interpreted and would not be confused with amyloid deposits in H\&E evaluation. We believe that this method could be interpreted incorrectly in 

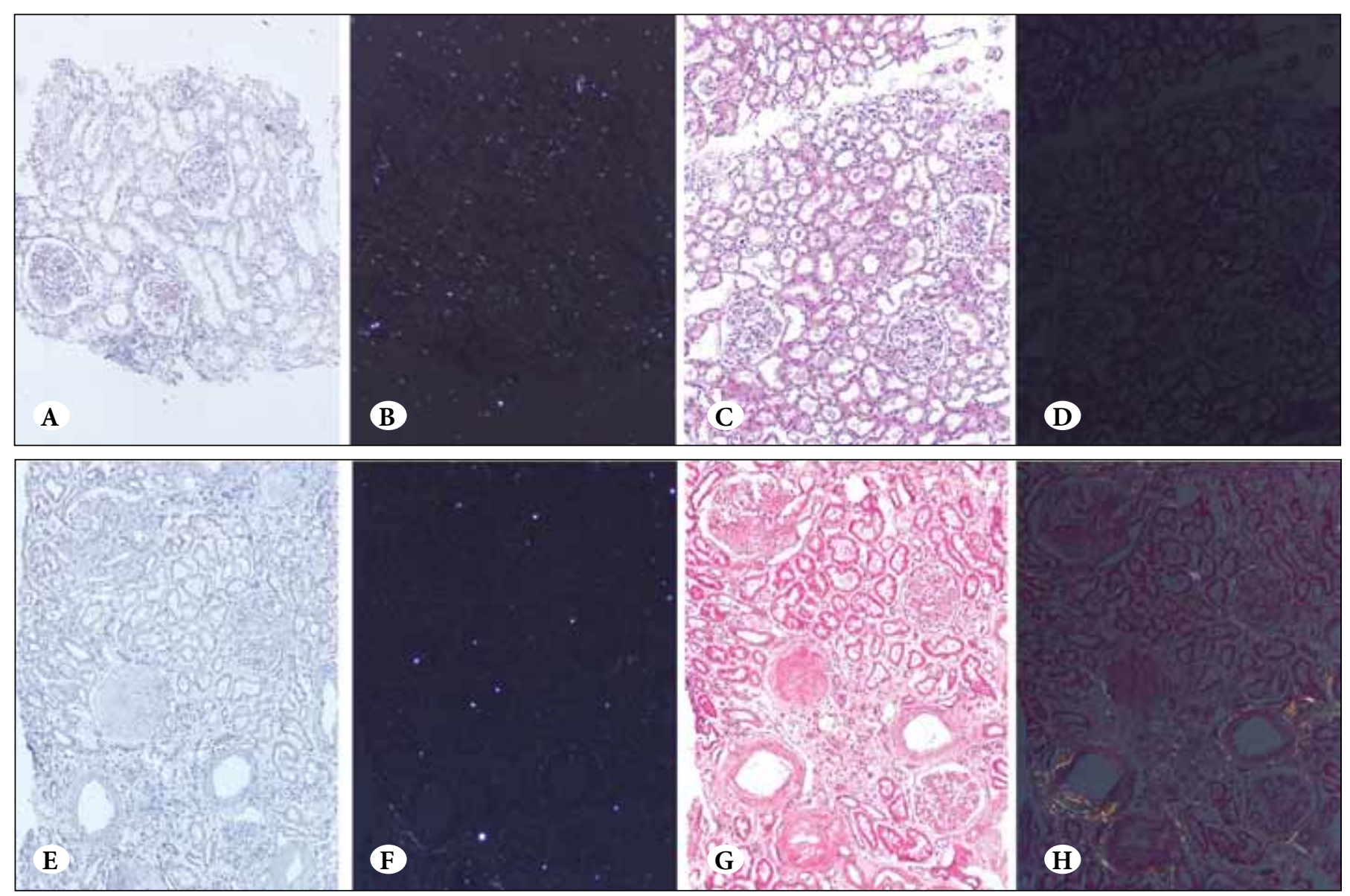

Figure 4: The comparison of polarization with the Congo red and $(\mathbf{A}, \mathbf{B}, \mathbf{E}, \mathbf{F})$ and hematoxylin-eosin $(\mathbf{C}, \mathbf{D}, \mathbf{G}, \mathbf{H})$ staining methods in cases with false negativity and positivity: In the negative case, it is seen that there is no double diffraction with (A) Congo red, (B) Congo red polarization, (C) Hematoxylin-eosin, (D) polarization with Hematoxylin-eosin. In the case with false positivity, (E) Congo red, (F) Congo red polarization is negative, $(\mathbf{G})$ Hematoxylin-eosin, $(\mathbf{H})$ polarization with Hematoxylin-eosin is present; Hematoxylin-eosin polarization is present in perivascular areas and in areas where deposits are not suspected (x100).

the evaluation of non-renal biopsies and especially in tissues such as skin and bone marrow that contain connective tissue or fibrosis areas and one should therefore be very careful and verify the results with new studies. Although it is not likely to be confused with amyloidosis, we used myeloma cast nephropathies as a negative control group due to the etiological similarity and light-chain amyloidosis (AL) relationship. $\mathrm{H} \& \mathrm{E}$ polarization was not seen in these cases.

H\&E polarization was barely noticed with an evaluation through the routine ocular but displaying the image through digital imaging and photography methods that we routinely use in our department and Picasa photography software easily available free of charge made the diagnosis of amyloidosis easy. We observed that the settings we defined for the Olympus DP 21 SAL camera system in this study were useful. It would be best to try digitally enhanced $\mathrm{H} \& \mathrm{E}$ polarization with different camera models and software from other manufacturers as well and to define the suitable settings according to each system followed by verification of the findings with CR. This can enable optimization for the diagnosis of amyloidosis of the digital cameras and software used in pathology practice. The routine use of digital H\&E polarization in the diagnosis and evaluation of amyloidosis with or without $\mathrm{CR}$ can then begin. Amyloid-specific software that will be written for this purpose can enable robotic scanning and recognition of amyloid deposits and optimize the diagnosis of amyloidosis. A similar change is currently observed with the use of new stains and fluorescent microscopy in the diagnosis of amyloid (19-21).

In cases where $\mathrm{H} \& \mathrm{E}$ polarization was not detected, we thought that it could be associated with subtypes of amyloid proteins. However, we were unable to query the relationship between amyloid types and false negativity as our rate was 
so low. Protein analysis with mass spectrophotometry and genetic studies are currently in the forefront due to the problems in typing of amyloid proteins with IHC (22-25). We defined the problems with IHC in another study where most of the cases of this study are also included (25). We avoided typing in cases with other amyloid protein staining close to AA staining and/or without clear clinical details. We therefore have a high rate of cases without typing. Our previous studies report AA amyloidosis rates reaching 90\% based solely on anti-AA IHC findings (6). However, we believe that false typing may have been done in non-AA amyloid cases in the past when only anti-AA IHC was used, when we take the case with myeloma and anti-AA IHC positivity into account $(24,25)$. We therefore avoided IHC typing in cases with suspicious IHC staining and clinical features in this study. The use of conjugated polyelectrolytes, a new staining method used on the fluorescent microscope, for the characterization of amyloid deposits and the possibility of employing amyloid-specific stains have been reported but there were problems regarding the sensitivity of the method (19-21).

In conclusion, digitally enhanced $\mathrm{H} \& \mathrm{E}$ polarization is a new method of amyloid evaluation. Sensitivity, specificity, and positive and negative predictive values close to the rates we determined in the kidney were found in upper gastrointestinal system amyloidosis cases (26). Digitally enhanced polarization was also investigated with toluidine blue used routinely for helicobacter pylori in the same series. High sensitivity and specificity values together with amyloid deposit polarization and anomalous color changes were also shown for toluidine blue (27). Digitally enhanced polarization is likely to be used with other staining methods in the diagnosis of amyloid. The use of this method with other staining methods for routine use is important for the preservation of the tissues.

When amyloidosis is suspected, practical, helpful and easy methods such as H\&E polarization reduce the workload of the laboratory and the cost of the diagnosis. We have started using digital analysis of $\mathrm{H} \& \mathrm{E}$ polarization before $\mathrm{CR}$ staining for differential diagnosis of amyloidosis in suspicious cases after renal needle biopsy. We believe it is important and necessary to conduct new studies with larger case series and by employing the various digital camera models and software used for non-renal tissues and pathology to put them into routine practice.

\section{ACKNOWLEDGEMENT}

We thank Dr. Nazan Özsan for enlightening us on hematoxylin-eosin staining polarization, Prof. Mine
Hekimgil for the Olympus DP 21 SAL used in the study, Gökçen Ertutar for the immunofluorescence test sections and staining, Hasibe Kömür and Hande Çolakoğlu for histochemical staining and Hayriye Köktaş and Dilek Pelvan for immunohistochemical staining.

\section{REFERENCES}

1. Sipe JD, Benson MD, Buxbaum JN, Ikeda S, Merlini G, Saraiva MJ, Westermark P: Amyloid fibril protein nomenclature: 2010 recommendations from the nomenclature Committee of the International Society of Amyloidosis. Amyloid 2010, 17:101-104

2. Larsen CP, Walker PD, Weiss DT, Solomon A: Prevalence and morphology of leukocyte chemotactic factor 2-associated amyloid in renal biopsies. Kidney Int 2010, 77:816-819

3. von Hutten H, Mihatsch M, Lobeck H, Rudolph B, Eriksson M, Röcken C: Prevalence and origin of amyloid in kidney biopsies. Am J Surg Pathol 2009, 33:1198-1205

4. Kebbel A, Röcken C: Immunohistochemical classification of amyloid in surgical pathology revisited. Am J Surg Pathol 2006, 30:673-683

5. Satoskar AA, Burdge K, Cowden DJ, Nadasdy GM, Hebert LA, Nadasdy T: Typing of amyloidosis in renal biopsies: diagnostic pitfalls. Arch Pathol Lab Med 2007, 131:917-922

6. Sen S, Sarsik B: A proposed histopathologic classification, scoring, and grading system for renal amyloidosis: standardization of renal amyloid biopsy report. Arch Pathol Lab Med 2010, 134 532-544

7. Hür E, Bozkurt D, Taşkın H, Sarsık B, Sen Ş, Akçiçek F, Duman $S$ : Yaşlılara yapılan böbrek biyopsileri artmaktadır: 12 yıllık Ege Üniversitesi deneyimi. Turkish Journal of Geriatrics 2011, 14: 289-294

8. Herrera GA, Picken MM: Renal diseases associated with plasma cell dyscrasias, amyloidoses, Waldenström macroglobulinemia and cryoglobulinemic nephropathies. In: Jennette JC, Olson JL, Schwartz MM, Silva FG, (Eds.), Heptinstalls Pathology of the Kidney. 6th ed., Philadelphia, Lippincott Williams \& Wilkins, 2006, 853-910

9. Appel TR, Richter S, Linke RP, Makovitzky J: Histochemical and topo-optical investigations on tissue-isolated and in vitro amyloid fibrils. Amyloid 2005, 12:174-183

10. Westermark GT, Johnson KH, Westermark P: Staining methods for identification of amyloid in tissue. Methods Enzymol 1999, 309:3-25

11. Puchtler H, Sweat F, Levine M: On the binding of Congo red by amyloid. J Histochem Cytochem 1962, 10:355-364

12. Argon A, Simşir A, Sarsik B, Tuna B, Yörükoğlu K, Niflioğlu GG Sen S: Amyloidosis of seminal vesicles; incidence and pathologic characteristics. Turk Patol Derg 2012, 28:44-48

13. Sen S, Başdemir G: Diagnosis of renal amyloidosis using Congo red fluorescence. Pathol Int 2003, 53:534-538

14. Sarsık B, Özsan N, Şen S: Renal Amiloidoz tanısında tioflavin T’nin önemi. Turk Patol Derg 2009, 25:6-12

15. Fernandez-Flores A: Positive staining with Congo red in tissues with heat artifact due to cautery. Rom J Morphol Embryol 2009, 50:203-206 
16. Howie AJ, Brewer DB, Howell D, Jones AP: Physical basis of colors seen in Congo red-stained amyloid in polarized light. Lab Invest 2008, 88:232-242

17. Howie AJ, Brewer DB: Optical properties of amyloid stained by Congo red: history and mechanisms. Micron 2009, 40:285-301

18. Howie AJ, Owen-Casey MP: Discrepancies between descriptions and illustrations of colours in Congo red-stained amyloid, and explanation of discrepant colours. Amyloid 2010, 17:109-117

19. Nilsson KP, Ikenberg K, Aslund A, Fransson S, Konradsson P, Röcken C, Moch H, Aguzzi A: Structural typing of systemic amyloidoses by luminescent-conjugated polymer spectroscopy. Am J Pathol 2010, 176:563-574

20. Sjölander D, Westermark GT, Westermark P, Hammarström P, Nilsson P: Luminescent conjugated oligothiophenes: two new dyes for amyloid screening diagnostics. XIII International Symposium on Amyloidosis May 6-10, 2012, Groningen. PA 59, Congress Book, 39-40

21. Kieninger B, Gioeva Z, Krüger S, Westermark GT, Friedrich RP, Fändrich M, Röcken C: PTAA and B10: new approaches to amyloid detection in tissue-evaluation of amyloid detection in tissue with a conjugated polyelectrolyte and a fibril-specific antibody fragment. Amyloid 2011, 18:47-52

22. Said SM, Sethi S, Cornell LD, Fidler ME, Hernandez LH, Vrana JA, Theis JD, Dogan A, Nasr SH: Renal Amyloidosis: Origin and Pathology of 445 Recent Cases from a Single Center. Available from: http://www.abstracts2view.com/uscap12/view. php?nu=USCAP12L_1688\&terms $=$ 23/4/2012 tarihinde erişildi
23. Sethi S, Fogo AB, Paueksakon P: Prevalence of Leukocyte Chemotactic Factor-2 (LECT-2) in Renal Amyloidosis. Available from: http://www.abstracts2view.com/uscap12/view.php?nu= USCAP12L_1698\&terms

24. Şen S, Sarsık B, Özsan N, Bozkurt D, Çağırgan S: AA dişı böbrek amiloidozlarında tanısal sorunlar. Turk Patol Derg 2010, 26: 14-24

25. Şen S, Sarsık B, Özsan N, Güngör Ö, Töz H: Renal amiloidozların alt tiplendirmesinde immunhistokimyanın yeri. 21. Ulusal Patoloji Kongresi, 16-20 Kasım, 2011, İzmir. S35. Turk Patol Derg 2011, 27(1):16

26. Pehlivanoglu B, Doganavsargil B, Sarsik B, Sezak M, Sen S: Dijitalized Hematoxylin-eosine slides: First clue in detection of amyloid depositions. XIII International Symposium on Amyloidosis, May 6-10, 2012, Groningen. PA57, Congress Book, 119-120

27. Sen S, Sarsik B, Pehlivanoglu B, Sezak M, Doganavsargil B: Dijitally reinforced Toluidine blue can safely be used for detection of amyloid depositions. XIII International Symposium on Amyloidosis May 6-10, 2012, Groningen. PA 59, Congress Book, 121-122 